\title{
POSSIBLE ROLE OF IRON DEFICIENCY IN OCCURRENCE AND RECURRENCE OF FEBRILE SEIZURES IN CHILDREN AGED 6-36 MONTHS
}

\author{
H. Atwa ${ }^{1}$, M. El-Kalioby ${ }^{1}$, A. Abdel-Hay ${ }^{2}$, A. Al-Samman ${ }^{1}$ \\ ${ }^{1}$ Pediatrics, ${ }^{2}$ Clinical Pathology, Faculty of Medicine - Suez Canal University, Ismailia, Egypt
}

Introduction: Febrile seizures are the most common type of seizures in children. Iron deficiency that affects about $46.5 \%$ of Egyptian children.

Aim: To investigate the relation of iron status and febrile seizures and its recurrence.

Methods: Fifty five children with febrile seizures (group 1) and 55 children with febrile illness with no seizures as control (group2) were included. Both group had no history or clinical examination suggesting neurological abnormalities. Hematological indices $\mathrm{HB}, \mathrm{MCV}, \mathrm{MCH}, \mathrm{MCHC}$ and RDW were measured in both groups. Iron status was assessed by serum iron, TIBC, transferrin saturation percentage (TS \%) and serum transferrin receptor(s-TFR).

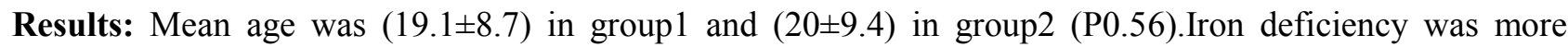
prevalent among children with FS $(60 \%)$ than control group $(29.1 \%) \mathrm{P}<0.01$.Children in group1 had significantly lower $\mathrm{HB}, \mathrm{MCV}$ and $\mathrm{MCH}$ than control group. Children with recurrence had significantly lower hemoglobin $(9.6 \pm 1.7)$ Vs $(10.8 \pm 1.3) \mathrm{P}<0.05$, serum iron $(36.6 \pm 4.9 \mu \mathrm{g} / \mathrm{dl}) \mathrm{Vs}(40.5 \pm 4.2 \mu \mathrm{g} / \mathrm{dl}) \mathrm{P}<0.05$ and serum transferring receptor (s-TFR) $(16.4 \pm 5.6) \mathrm{mg} / \mathrm{l} \mathrm{Vs}(11.8 \pm 2.6 \mathrm{mg} / \mathrm{l}) \mathrm{P}<0.05$ compared to those with no recurrence. There was positive correlation between iron deficiency and recurrence of febrile seizures. There was no relation between type of seizures either focal or generalized socioeconomic state, type of infection and occurrence of febrile seizure. There was no relation between type of seizures either focal or generalized and iron status.

Conclusion: Iron deficiency could play a role in occurrence and recurrence of febrile seizures. 